\title{
TINGKAT KEBUGARAN JASMANI BERDASARKAN INDEKS MASSA TUBUH PADA SISWA SMP NEGERI 29 BENGKULU UTARA
}

\author{
Edo Prasetio \\ PENJAS FKIP UNIB, e-mail: edoprasetiosiran31@gmail.com \\ Ari Sutisyana \\ Universitas Bengkulu \\ Bogy Restu llahi \\ Universitas Bengkulu \\ Defliyanto \\ Universitas Bengkulu
}

\begin{abstract}
Abstrak
Penelitian ini bertujuan untuk mengetahui tingkat kebugaran jasmani berdasarkan indeks massa tubuh pada siswa SMP Negeri 29 Bengkulu Utara. Penelitian dilakukan dengan melakukan tes kebugaran jasmani dan tes antropometri pada siswa SMP Negeri 29 Bengkulu Utara. Sampel penelitian ini diambil dengan teknik Cluster Sampling. Analisis data yang di gunakan dalam penelitian ini adalah menggunakan persentase untuk menggambarkan frekuensi dan persentase dari data yang diperoleh. Hasil penelitian menyatakan bahwa $68 \%$ siswa memliki indeks massa tubuh yang kurang, 18\% siswa memiliki indeks massa tubuh normal, dan $14 \%$ siswa memiliki indeks massa tubuh gemuk. Sedangkan tingkat kebugaran jasmani siswa menunjukkan 39\% kurang, 42\% sedang, dan 19\% baik. Sehingga dapat disimpulkan bahwa tingkat kebugaran jasmani dan indeks massa tubuh pada siswa SMP Negeri 29 Bengkulu Utara masih rendah.
\end{abstract}

Kata kunci: tingkat kebugaran jasmani, indeks massa tubuh.

\begin{abstract}
The aim of this study is to find out the vitality level based on the body mass index on students of SMP Negeri 29 Bengkulu Utara. This study was conducted by performing physical vitality tests and anthropometric tests on Students of SMP Negeri 29 Bengkulu Utara. The samples of this study were takenfrom cluster sampling technique. Data analysis used in this study was the using of percentage to describe frequency and percentage of data obtained. The results showed that $68 \%$ of students had a low body mass index, $18 \%$ of students had a normal body mass index, and $14 \%$ of students had a fat body mass index. While the students' physical vitalitylevels
\end{abstract}


showed 39\% less, $42 \%$ moderate, and $19 \%$ good. Therefore, it can be concluded that the level of physical vitality and body mass index on students SMP Negeri 29 Bengkulu Utara still low.

Keywords: physical vitality level, body mass index

\section{PENDAHULUAN}

Pendidikan jasmani merupakan bagian penting dari pendidikan secara keseluruhan, yang bertujuan untuk mengembangkan aspek kebugaran jasmani, keterampilan gerak, keterampilan berfikir kritis, keterampilan sosial, penalaran, stabilitas emosional, aspek pola hidup sehat dan pengenalan lingkungan bersih melalui aktivitas jasmani yang direncanakan secara sistematis dalam rangka mencapai tujuan pendidikan nasional. Salah satu apek yang perlu ditingkatkan melalui pendidikan jasmani untuk mencapai tujuan pendidikan nasional yaitu tingkat kebugaran jasmani siswa.

Menurut Roji (2009:56) kebugaran jasmani (physical fittnes) merupakan salah satu aspek fisik dari kesegaran menyeluruh (total fittnes). Kebugaran jasmani memberikan kesanggupan kepada sesorang untuk melakukan pekerjaan yang produktif seharihari tanpa adanya kelelahan berlebihan dan masih mempunyai cadangan tenaga untuk menikmati waktu senggangnya dengan baik maupun melakukan aktivitas yang mendadak. Menurut Agutini Utari (2007:28) kebugaran jasmani memiliki dua komponen utama, yaitu : komponen kebugaran yang berkaitan dengan kesehatan antara lain : kekuatan otot, daya tahan otot, daya tahan aerobik, kelenturan. Serta komponen kebugaran jasmani yang berkaitan dengan keterampian antara lain : koordinasi, kelincahan, kecepatan gerak, daya ledak otot, dan keseimbangan.
Komponen-komponen kebugaram jasmani adalah faktor penentu derajat kondisi setiap individu. Seseorang dikatakan bugar jika mampu melakukan segala aktivitas kehidupan sehari-hari tanpa mengalami hambatan yang berarti dan dapat melakukan tugas berikutnya dengan segera.

Dari beberapa pendapat dapat tersebut disimpulkan bahwa kebugaran jasmani adalah kualitas seseorang untuk melakukan aktivitas sesuai dengan pekerjaannya secara optimal tanpa menimbulkan masalah kesehatan dan kelelahan yang berlebihan. Saat ini siswa cenderung menghentikan aktivitas yang banyak menuntut keluarnya banyak tenaga. Mereka telah banyak dibebani oleh tugastugas sekolah, tugas-tugas di rumah, kegiatan ekstrakurikuler sehingga mereka tidak memiliki waktu yang banyak untuk melakukan aktivitas yang dapat meningkatkan kebugaran jasmani mereka. Hal ini tentu banyak mempengaruhi kebiasaaan makan dan aktivitas gerak mereka dan memungkinkan terjadinya obesitas dan kekurangan berat badan (kurus) pada siswa. Obesitas pada anak terjadi karena tidak seimbangnya antara energi yang masuk dengan energi yang dikeluarkan. Artinya siswa tersebut banyak makan tetapi kekurangan akiitas fisik. Sementara kurus pada siswa terjadi karena energi yang dikeluarkan lebih besar daripada jumlah energi yang masuk. Cara menentukan obesitas dan kurusnya siswa yaitu dengan menggunakan Indeks Massa Tubuh (IMT). Pengukuran IMT ini hanya membutukan 2 hal, yaitu tinggi badan dan berat badan. 
Berdasarkan hasil pengamatan yang telah dilakukan di SMP Negeri 29 Bengkulu Utara ternyata masih terdapat kendala dalam hal kebugaran jasmani siswa. Kendala yang ditemukan pada SMP Negeri 29 Bengkulu Utara adalah siswa kekurangan aktivitas gerak terbukti dengan sedikitnya siswa yang mengikuti kegiatan ekstrakurikuler olahraga. Dapat disimpulkan, siswa hanya melakukan aktivitas gerak pada saat pelajaran pendidikan jasmani dan senam kebugaran setiap hari Jum'at.

Peningkatan kebugaran jasmani di lingkungan sekolah perlu dibina untuk menunjang tercapainya proses belajar yang optimal. Jika siswa memiliki tingkat kebugaran jasmani yang baik akan dapat melakukan kewajiban belajarnya dengan baik. Namun, apabila siswa memiliki tingkat kebugaran jasmani yang buruk dimungkinkan akan tidak mampu menerima beban belajar. Mengingat pentingnya kebugaran jasmani pada siswa dan kecenderungan peningkatan tingkat obesitas maka perlu diadakan penelitian mengenai penilaian indeks massa tubuh terhadap tingkat kebugaran jasmani pada siswa. Penelitian ini dilakukan untuk mengetahui indeks massa tubuh yang baik untuk tingkat kebugaran jasmani pada siswa.

Berdasarkan permasalahan yang telah dikemukakan diatas peneliti tertarik untuk melakukan penelitian mengenai "Studi Kasus Tingkat Kebugaran Jasmani Berdasarkan Indeks Massa Tubuh Pada Siswa SMP Negeri 29 Bengkulu Utara Tahun Ajaran 2016/2017".

\section{METODE}

Penelitian ini menggunakan metode penelitian kualitatif. Menurut Sugiyono (2006:8) metode penelitian kualitatif adalah metode penelitian yang berlandaskan sebagai metode penelitian yang berlandaskan pada filsafat postpositivisme, digunakan untuk meneliti pada kondisi objek ilmiah dimana peneliti adalah sebagai instrumen kunci, analisis data bersifat induktif dan hasil penelitian lebih menekankan pada makna. Makna adalah data yang sebenarnya sedangkan objek ilmiah adalah objek yang berkembang apa adanya, tidak dimanipulasi dan kehadiran peneliti tidak mempengaruhi dinamika pada objek tersebut.

Pengambilan sampel dalam penelitian ini adalah dengan menggunakan teknik pengambilan Cluster Sampling. Menurut Sugiyono (2011:83) Cluster Sampling adalah teknik sampling yang digunakan untuk menentukan sampel bila objek yang diteliti atau sumber data sangat luas. Untuk menjadikan sampel sebagai sumber data, maka pengambilan sampelnya berdasarkan daerah/kelas populasi yang telah ditetapkan. Dalam penelitian ini diambil satu dari setiap tingkat yaitu kelas VII B dengan 33 siswa yang terdiri atas 17 siswa perempuan dan 16 siswa laki-laki serta kelas VIII A dengan 29 siswa yang terdiri atas 15 siswa perempuan dan 14 siswa laki-laki. Jadi, jumlah siswa yang menjadi sampel dalam penelitian ini yaitu 62 siswa yang terdiri atas 32 siswa perempuan dan 30 siswa laki-laki.

Pengumpulan data untuk penelitian ini yaitu dengan melakukan pengukuran antropometri. Kemudian diukur Indeks Massa Tubuh dan dikategorikan berdasarkan status gizinya. Cara menentukan indeks massa tubuh yaitu dengan rumus :

$$
\mathrm{IMT}=\frac{\text { berat } \text { badan }(\mathrm{kg})}{(\operatorname{ting} \operatorname{gi} \text { badan }(\mathrm{m}))^{2}}
$$

Tabel 1. Nilai IMT berdasarkan status gizi

\begin{tabular}{|c|c|c|}
\hline IMT & $\begin{array}{c}\text { Status } \\
\text { Gizi }\end{array}$ & Keterangan \\
\hline$<17,0$ & Kurus & Kekurangan berat \\
\hline
\end{tabular}




\begin{tabular}{|c|c|c|}
\hline & & badan tingkat berat \\
\hline $17,0-18,5$ & & $\begin{array}{l}\text { Kekurangan berat } \\
\text { badan tingkat ringan }\end{array}$ \\
\hline $18,5-25,0$ & Normal & Normal \\
\hline $25,0-27,0$ & \multirow[t]{2}{*}{ Gemuk } & $\begin{array}{c}\text { Kelebihan berat } \\
\text { badan tingkat ringan }\end{array}$ \\
\hline$>27,0$ & & $\begin{array}{c}\text { Kelebihan berat } \\
\text { badan tingkat berat }\end{array}$ \\
\hline
\end{tabular}

Sumber : Waryana dalam Ayu Putri Ariani (2017:60)

Setelah diperoleh indeks massa tubuh dan ketegori status gizinya maka selanjutnya akan dilakukan tes kebugaran jasmani. Tes kebugaran jasmani yang dipilih dalam penelitian ini adalah Tes Kebugaran Jasmani Indonesia (TKJI).

Tes TKJI merupakan suatu perangkat tes lapangan untuk anak usia 6-9 tahun, 10-12 tahun, 13-15 tahun, 16-19 tahun. Setiap kelompok usia dan jenis kelamin merupakan rangkaian tes yang masing-masing terdiri dari 5 butir tes yang dilakukan secara berurutan. Kelima butir tes untuk setiap kelompok usia tingkat SMP yaitu 13-15 tahun berdasarkan jenis kelamin adalah sebagai berikut :

- Putra : lari cepat 50 meter, gantung angkat tubuh, baring duduk 60 detik, loncat tegak, lari jarak menengah 1000 meter.

- Putri : lari cepat 50 meter, gantung siku tekuk, baring duduk 60 detik, loncat tegak, lari jarak menengah 800 meter.

Tabel. 2

Norma klasifikasi tingkat kebugaran tes TKJI

\begin{tabular}{|c|c|c|}
\hline No & Jumlah Nilai & Klasifikasi \\
\hline 1 & $22-25$ & Baik Sekali \\
\hline 2 & $18-21$ & Baik \\
\hline 3 & $14-17$ & Sedang \\
\hline 4 & $10-13$ & Kurang \\
\hline 5 & $5-9$ & Kurang Sekali \\
\hline
\end{tabular}

Sumber : Arsil (2010:78)
Setelah data terkumpul dari penelitian, maka data tersebut akan dianalisis dengan menggunakan teknik analisis deskriptif yaitu dengan mendeskripsikan atau menggambarkan data yang telah terkumpul, maka analisis data yang digunakan yaitu dengan menggambarkan frekuensi dan persentase dari data tersebut. yaitu dengan rumus sebagai berikut :

$\mathrm{P}=\frac{F}{N} \times 100 \%$

Keterangan : $\mathrm{P}=$ Persentase.

$\mathrm{F}=$ Frekuensi.

$\mathrm{N}=$ Jumlah Sampel.

Sumber: Suharsimi Arikunto (2006:243)

\section{HASIL DAN PEMBAHASAN}

Hasil

Subjek penelitian diminta untuk melakukan tes antropometri dan tes kebugaran jasmani Indonesia.

Tes antropometri

Tes antropometri ini mengukur tinggi dan berat badan siswa, tes ini dugunakan untuk mengetahui nilai indeks massa tubuh siswa dan kemudian ditentukan status gizi siswa tersebut. Setelah dilakukan tes pada subjek sebanyak 62 siswa diperoleh hasil sebagai berikut.

Tabel 3.

Hasil tes antropometri

\begin{tabular}{|c|c|c|}
\hline No & Status Gizi & Jumlah Siswa \\
\hline 1 & Kurus & 42 \\
\hline 2 & Normal & 11 \\
\hline 3 & Gemuk & 9 \\
\hline & Total & 62 \\
\hline
\end{tabular}

Dari hasil tes antropometri diketahui bahwa 42 siswa memiliki status gizi kurus, 11 siswa memiliki status gizi normal, dan 9 siswa memiliki status gizi gemuk. 
Tes kebugaran jasmani Indonesia

Tes kebugaran jasmani Indonesia terdiri atas 5 tes yaitu tes lari jarak pendek 50 meter, tes gantung angkat tubuh (laki-laki)/tes gantung siku tekuk (perempuan), tes baring duduk 60 detik, tes loncat tegak, tes lari jarak menengah 1000 meter (laki-laki)/800 meter (perempuan).

Berikut ini adalah hasil tes kebugaran jasmani Indonesia yang telah dilaksanakan pada subjek 62 siswa.

Tabel 4.

Hasil tes kebugaran jasmani

\begin{tabular}{|c|c|c|}
\hline No & $\begin{array}{c}\text { Klasifikasi tingkat } \\
\text { kebugaran jasmani }\end{array}$ & $\begin{array}{c}\text { Jumlah } \\
\text { siswa }\end{array}$ \\
\hline 1 & Kurang & 24 \\
\hline 2 & Sedang & 26 \\
\hline 3 & Baik & 12 \\
\hline & Total & 62 \\
\hline
\end{tabular}

Dari hasil tes kebugaran jasmani diketahui bahwa sebanyak 24 siswa memliki tingkat kebugaran jasmani kurang, 26 siswa memiliki tingkat kebugaran jasmani sedang, dan 12 siswa memiliki tingkat kebugaran jasmani yang baik.

Pembahasan

Indeks Massa Tubuh

Tabel 5.

Indeks massa tubuh

\begin{tabular}{|c|c|c|}
\hline IMT & Jumlah & Persentase \\
\hline Kurus & 42 & $68 \%$ \\
\hline Normal & 11 & $18 \%$ \\
\hline Gemuk & 9 & $14 \%$ \\
\hline Total & 62 & $100 \%$ \\
\hline
\end{tabular}

Tabel menunjukkan bahwa 42 siswa atau sebesar 68 \% siswa SMP Negeri 29 Bengkulu Utara mempunyai status gizi kurus, 11 siswa atau sebesar $18 \%$ siswa mempunyai status gizi normal, dan 9 siswa atau sebesar 14 $\%$ siswa mempunyai status gizi gemuk.
Tingkat Kebugaran Jasmani

Tabel 6.

Tingkat kebugaran jasmani

\begin{tabular}{|c|c|c|}
\hline Kebugaran Jasmani & Jumlah & Persentase \\
\hline Kurang & 24 & $39 \%$ \\
\hline Sedang & 26 & $42 \%$ \\
\hline Baik & 12 & $19 \%$ \\
\hline Total & 62 & $100 \%$ \\
\hline
\end{tabular}

Tabel menunjukkan bahwa 24 siswa atau sebesar 39 \% siswa SMP Negeri 29 Bengkulu Utara mempunyai tingkat kebugaran jasmani kurang, 26 siswa atau sebesar $42 \%$ siswa mempunyai tingkat kebugaran jasmani sedang, dan 12 siswa atau sebesar 19 \% siswa mempunyai tingkat kebugaran jasmani baik.

Kebugaran jasmani berdasarkan indeks massa tubuh

a. Siswa dengan indeks massa tubuh kurus

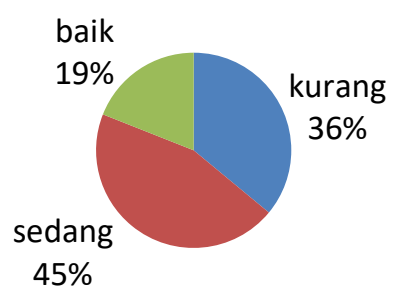

Dari diagram dapat digambarkan bahwa dari 42 siswa yang memiliki IMT kurus terdapat $36 \%$ siswa memiliki tingkat kebugaran jasmani kurang, 45\% siswa memiliki tingkat kebugaran jasmani sedang, dan 19\% siswa memiliki tingkat kebugaran jasmani baik.

b. Siswa dengan indeks massa tubuh normal

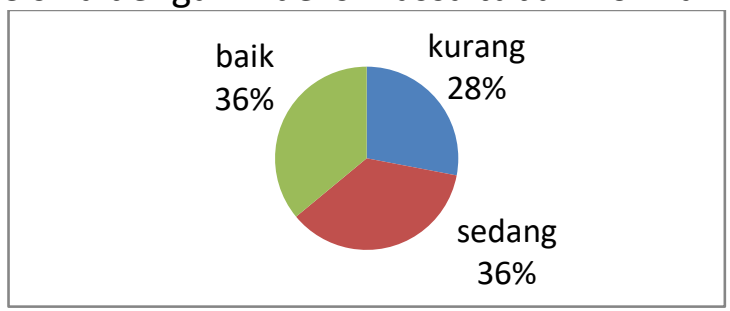


Dari diagram dapat digambarkan bahwa dari 11 siswa yang memiliki IMT normal terdapat 28\% siswa memiliki tingkat kebugaran jasmani kurang, 36\% siswa memiliki tingkat kebugaran jasmani sedang, dan $36 \%$ siswa memiliki tingkat kebugaran jasmani baik.

\section{c. Siswa dengan indeks massa tubuh baik}

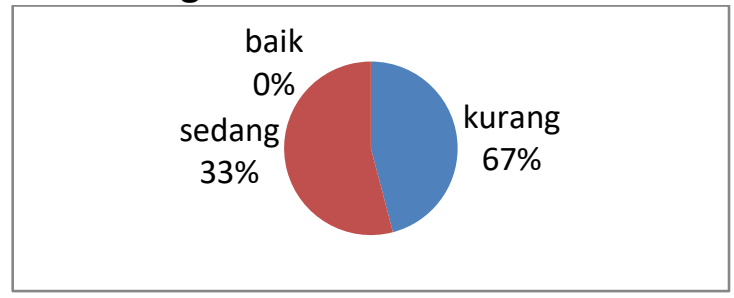

Dari diagram dapat digambarkan bahwa dari 11 siswa yang memiliki IMT normal terdapat $28 \%$ siswa memiliki tingkat kebugaran jasmani kurang, 36\% siswa memiliki tingkat kebugaran jasmani sedang, dan $36 \%$ siswa memiliki tingkat kebugaran jasmani baik.

\section{PENUTUP}

\section{Simpulan}

Berdasarkan hasil penelitian yang telah dilakukan di SMP Negeri 29 Bengkulu Utara maka dapat disimpulkan sebagai berikut :

1. Siswa SMP Negeri 29 Bengkulu Utara sebagian besar memiliki indeks massa tubuh kurus.

2. Siswa SMP negeri 29 Bengkulu Utara sebagian besar memiliki tingkat kebugaran jasmani sedang.

3. Siswa yang memiliki indeks massa tubuh kurus memiliki tingkat kebugaran jasmani sedang.
4. Siswa yang memiliki indeks massa tubuh normal memiliki tingkat kebugaran jasmani sedang dan baik.

5. Siswa yang memiliki indeks massa tubuh gemuk memiliki tingkat kebugaran jasmani kurang.

6. Dari data yang diperoleh diketahui bahwa semakin tinggi nilai indeks massa tubuh semakin rendah tingkat kebugaran jasmani. Hal ini dibuktikan dengan tidak adanya siswa yang memiliki indeks massa tubuh gemuk dan memiliki tingkat kebugaran jasmani yang baik.

\section{Saran}

Dari hasil penelitian ini, peneliti dapat memberikan saran sebagai berikut:

1. Sekolah

Perlu adanya upaya dari sekolah untuk meningkatkan tingkat kebugaran jasmani dengan menurunkan tingkat indeks massa tubuh siswa yaitu salah satunya dengan olahraga kontinyu dan ritmik yang melibatkan sebagian otot-otot tubuh, misalnya berlari, senam ritmik, berenang.

2. Guru pendidikan jasmani dan kesehatan

Peranan guru pendidikan jasmani dan kesehatan disekolah perlu ditingkatkan lagi yaitu dengan mengoptimalkan kembali jam pelajaran pendidikan jasmani dan kesehatan sehingga siswa dapat banyak melakukan aktivitas gerak dan diharapkan dapat meningkatkan tingkat kebugaran jasmani siswa.

\section{Orang tua siswa}

Untuk orang tua siswa diaharapkan untuk memperhatikan asupan gizi anak yang seimbang dimana anak masih dalam tahap perkembangan yang membutuhkan gizi yang baik bukan hanya membantu aktivitas anak 
dan kebugaran jasmani anak tetapi juga dapat meningkatkan prestasi sekolah dengan menjaga status gizi yang baik.

\section{DAFTAR PUSTAKA}

Agutini Utari. (2007). Hubungan Indeks Massa Tubuh Dengan Tingkat Kebugaran Jasmani Pada Usia 12-14 Tahun. Tesis. Semarang: Fakultas Kedokteran Universitas Diponegoro.

Arikunto, Suharsimi. (2006). Prosedur Penelitian Suatu Pendekatan Praktik. Jakarta: Rineka Cipta.

Ariani, A.P. (2017). Ilmu Gizi. Yogyakarta: NuhaMedika.

Arsil. (2010). Evaluasi Penjas Dan Olahraga. Padang.

Roji. (2006). Pendidikan Jasmani, Olahraga, dan Kesehatan Untuk SMP/MTs Kelas VII. Jakarta: Erlangga.

Sugiyono. (2006). Metode Penelitian Kuantitatif, Kualitatif Dan R\&D. Bandung: Alfabeta.

(2011). Metode Penelitian Kuantitatif, Kualitatif Dan R\&D. Bandung: Alfabeta.

Tangkudung, James. (2012). Kepelatihan Olahraga Pembinaan Prestasi Olahraga. Jakarta: Cerdas jaya ,(2016).Macam-macam

Metodologi Penelitian. Jakarta: Lensa Media Pustaka Indonesia

Dasar-dasar dan instrument Psikometri. Depok :Rajagrafindo persada 